VII междунар. науч.-практ. конф., Санкт-Петербург, РГПУ им. А.И. Герцена, 24-25 октября 2018 года. СПб., 2018. С. 143-166.

17. Копелев Д.Н. Пиратство в XVI-XVIII веках: на острие мировой политики. СПб.: Вита Нова, 2013. $734 \mathrm{c}$.

18. Копелев Д.Н. Раздел Океана в XVI-XVIII веках: истоки и эволюция пиратства. СПб.: Крига, 2013. $736 \mathrm{c}$.

19. Губарев В.К. Фрэнсис Дрейк. М.: Молодая гвардия, 2013. $374 \mathrm{c}$.

20. The World Encompassed by Sir Francis Drake / ed. by W.S.W. Vaux. L.: Hakluyt Society, 1854. 295 p.

21. Voyages of Hawkins, Frobisher and Drake. Select narratives from the «Principal Naviagations» / ed. by E.J. Payne. Oxford: Clarendon Press, 1907. 280 p.
22. New Light on Drake: A Collection of Documents Relating to His Voyage of Circumnavigation, 15771580 / ed. by Z. Nuttall. L.: Hakluyt Society, 1914. $443 \mathrm{p}$.

23. Hakluytus Posthumus, or Purchas His Pilgrimes, contayning a History of the World, in Sea Voyages, and Lande Travells by Englishmen and others / ed. by S. Purchas. Vol. 16. Glasgow: James MacLehose and Sons, 1906. 579 p.

24. D'Avila de Mello A. Peter Carder's Strange Adventures Revealed // The Mariner's Mirror. 2007. Vol. 93, № 3. P. 261-268.

25. Calendar of Letters and State Papers Relating to English Affairs, Preserved Principally in the Archives of Simancas / ed. by M. Hume. Vol. II. 1568-1579. L.: Public Record Office, 1894. 742 p.

\title{
A FAILED CIRCUMNAVIGATION OF «ELIZABETH»
}

(C) 2019

Mikheev Dmitry Vladimirovich, candidate of historical sciences, associate professor of World History Department; associate professor of World History and Area Studies Department Herzen State Pedagogical University of Russia (Saint Petersburg, Russian Federation); Pskov State University (Pskov, Russian Federation)

Abstract. The second circumnavigation, accomplished by the Englishman under the leadership of Francis Drake, followed the expedition of Magellan to one of the most important enterprises of the Age of Discovery. The expedition members who returned with Drake on the «Golden hind» became heroes and were enriched by the robbery of the Spanish colonies on the Pacific coast of America. However, another ship was able to return to England under the command of Captain Winter. We can judge about his journey, relying on the few reports and diaries of two members of the crew of «Elizabeth» - notes of John Cook and more detailed notes of Edward Cliff. The Vice-Admiral's ship «Elizabeth», having lost the flagship of the expedition, was thrown back into the Strait of Magellan and returned to its homeland across the Atlantic, without having made a circumnavigation. The choice of the way back and the refusal to continue the expedition was the sole decision of Captain Winter. Attempts to go along the Brazilian coast in order to achieve profitability by means of trade or robbery led to serious losses among the crew and the prosecution of the Captain Winter. Probably for this reason British studies don't pay any serious attention to the journey of «Elizabeth».

Keywords: circumnavigation; Anglo-Spanish relations; Portuguese colonies; New World; Brazilian coast; Strait of Magellan; South Sea; he Atlantic; Francis Drake; Francis Fletcher; John Cook Edward Cliff; Peter Carder; Bernardino de Mendoza; Elizabeth Tudor; Captain Winter.

УДК 93/94

DOI 10.24411/2309-4370-2019-11205

Статья поступила в редакцию 11.01.2019

\section{УЧАСТИЕ АРМЯНСКОЙ АПОСТОЛЬСКОЙ ЦЕРКВИ В ОБРАЗОВАТЕЛЬНОЙ И АДМИНИСТРАТИВНОЙ ДЕЯТЕЛЬНОСТИ ЛАЗАРЕВСКОГО ИНСТИТУТА ВОСТОЧНЫХ ЯЗЫКОВ}

(C) 2019

\author{
Аветисян Владимир Рудольфович, кандидат исторических наук, \\ заведующий отделом публикации документов \\ Государственньй архив Ставропольского края (2. Ставрополь, Российская Федеращия)
}

\begin{abstract}
Аннотащия. Институт восточных языков (Лазаревский институт) на протяжении своего существования (1815-1921) претерпел ряд преобразований, а именно: начав свою деятельность с частного училища, он достиг статуса государственного высшего учебного заведения. Понимая особую роль религии в сохранении этнических особенностей армянской нации в условиях отсутствия государственности, видные российские общественные и государственные деятели Лазаревы способствовали укреплению статуса церкви в стенах института. Представители Армянской Апостольской церкви (ААЦ) оказывали всяческое содействие образовательному и воспитательному процессу сначала в училище, а затем и в институте. Апогеем стало юридическое закрепление в 1841 г. прав ААЦ на непосредственное участие в осуществлении руководства институтом и получение католикосом статуса почетного члена института. Многие армянские священнослужители внесли существенный вклад в развитие образовательного учреждения, выступая гарантом культурных основ армянского народа. При содействии церкви в Лазаревском институте действовали новые направления, учреждались стипендии и публиковалась литература. Полученные в ходе исследования материалы могут служить основой для дальнейшего изучения роли церковных организаций в образовательной жизни средних и высших учебных заведений страны.
\end{abstract}


Ключевые слова: Армянская Апостольская церковь; Армяно-григорианская церковь; Лазаревский институт восточных языков; Армянское московское училище; Лазаревы; образование; духовное отделение; специальные классы; церковные стипендии; армянская община; Москва; Католикос всех армян Ефрем; патриарх Hepcec.

Представители семейного рода Лазаревых вошли в историю России второй половины XVIII-XIX вв. не только как видные государственные деятели и предприниматели, но и как крупные благотворители и меценаты. Благодаря их деятельности, в 1815 г. в Москве состоялось открытие Армянского московского училища, преобразованного в 1827 г. в Лазаревский институт восточных языков и отнесенного правительствующим указом 1835 г. «во второй разряд правительственных учебных заведений» [1, л. 2]. За свою чуть более чем вековую историю институт стал крупнейшим армянским образовательным учреждением Российской империи, в котором отдельную роль играла Армянская Апостольская церковь (в дореволюционной историографии именуемая также как Армяно-григорианская церковь).

История изучения Лазаревского института как образовательного учреждения XIX - начала XX вв. ранее не раз затрагивалась в трудах советских и постсоветских отечественных историков, в первую очередь в трудах А.П. Базиянца [2], А.А. Игнатяна [3], Ж.А. Ананян [4], С.М. Саядова [5] и др. Несмотря на это, в настоящее время существует ряд аспектов, требующих более детального изучения, в частности - оценка роли Армянской Апостольской церкви в деятельности Лазаревского института, что и послужило целью данного исследования.

\section{Община и цеерковь}

Прежде чем определять основные направления деятельности Армянской Апостольской церкви (ААЦ) в стенах института, необходимо выявить исторические предпосылки, способствовавшие приобщению церкви к управлению столичным образовательным учреждением. С этой целью обратимся к рассмотрению армянских общин Москвы и Санкт-Петербурга, которые уже во второй половине XVIII в. начали активно развиваться.

Говоря об истории армянских общин двух столиц, исходя из проблематики заявленной темы, следует более детально остановиться на вкладе в их развитие представителей семьи Лазаревых. Важным фактором в сохранении и развитии этнической самобытности общины Лазаревы считали духовное воспитание армянского народа, достичь которого можно было через церковь. Так, на средства главы семьи Лазаря Назаровича Лазарева (1700-1782) и его старшего сына Ивана Лазаревича (1735-1801) в СанктПетербурге на Невском проспекте в 1771 г. была построена армянская церковь, названная в честь Св. Екатерины. Позже, в первой половине XIX в., духовный пастырь и знаток армянской литературы отец Хорен основал при церкви хор, состоявший из молодых людей, обучавшихся в средних и высших учебных заведениях Санкт-Петербурга.

После смерти Ивана Лазаревича строительство армянских церквей продолжил его брат Мина Лазаревич Лазарев (1737-1809). Благодаря его активной общественной позиции, в 1808 г. на Ваганьковском поле в Москве состоялось открытие церкви Сурб Арутюн (Воскрешения Христова), рядом с которой расположилось «армянского исповедания кладбище» [6, с. 9]. Мина Лазаревич считался сторонником прорусской ориентации Армении и всячески содействовал присоединению закавказских областей к Российской империи. Возможно, благодаря именно этим заслугам правительство не препятствовало строительству церквей под его руководством. Также примечателен и тот факт, что с 1801 по 1809 гг. он занимал должность попечителя армянских церквей Москвы и Петербурга и представителя всех армян в столице России. Младший из Лазаревых - Христофор Лазаревич (1741-1774), как и старшие братья, занимался храмовым строительством в Москве. Однако при сооружении одного из них простудился и вскоре умер. Открытие вышеназванных соборов имело важную историческую значимость, поскольку вплоть до начала XIX в. армянские религиозные учреждения страны не были признаны юридическим лицом, за которым закреплялись бы официальные имущественные права.

Отношение к армянским религиозным организациям начало изменяться только во второй трети XIX в., когда Указом императора Николая I от 11 марта 1836 г. было утверждено «Положение об управлении делами Армяно-Григорианской Церкви в России» [7, с. 600-601], согласно которому Армянская церковь могла претендовать на собственное церковное имущество. Во многом такие колебания в правительствующих кругах объясняются общей внешнеполитической обстановкой и были связаны с интересами российского государства в Закавказье. Тем не менее процесс объединения армян и появление в разных русских городах страны армянских храмов свидетельствовали об укреплении позиции Армянской Апостольской церкви в России. Таким образом, следует сделать вывод, что в сохранении духовных основ армянской нации Лазаревы уделяли особое место именно церкви.

\section{Участие в управлении институтом}

Представители семьи Лазаревых одной из своих задач видели способствование интеграции армянского населения в российское общество и приобщении его к русской передовой культуре (с присоединением в 1828 г. Эриванского ханства к России данное стремление стало более актуальным). Один из главных способов осуществления задуманного они видели в образовании. Уже во второй половине XVIII в. Иван Лазаревич Лазарев приступил к разработке проекта организации образовательного учреждения, в котором дети из армянских семей смогли бы получить достойное по тем временам образование. Уникальностью данного учреждения должно было стать осуществление интеграции армянских детей в российское общество при сохранении этнических особенностей. Иван Лазаревич скончался в 1801 г., так и не успев осуществить начатое. Его идеи воплотил в жизнь брат - Иоаким Лазаревич, который на средства, оставленные братом, открыл в 1815 г. в Армянском переулке города Москвы Армянское Московское господ Лазаревых Училище [8, л. 3-5]. 
В фондах центральных архивов Москвы (Российский государственный архив древних актов, Центральный государственный архив Москвы) и СанктПетербурга (Российский государственный исторический архив) сохранились уникальные документальные свидетельства об истории формирования и развития Лазаревского института восточных языков. Благодаря анализу накопленного в архивах материала можно проследить роль Армянской Апостольской церкви в образовательном процессе института с момента его учреждения. Условно ее можно подразделить на следующие категории: участие в управлении институтом, деятельность духовного отделения института, церковные стипендии, публикационная деятельность. Рассмотрим каждое направление подробнее.

В 1815 г. в Армянском московском училище начались первые занятия. Для работы в училище Лазаревы пригласили священнослужителя ААЦ Артемия Мануковича Аламдаряна (1796-1834), который самостоятельно вел все предметы. Исключением являлось лишь преподавание русского языка, для которого приглашался отдельный преподаватель $[9$, с. 2]. Заслуга А.М. Аламдаряна заключалась в том, что он подготовил русскую грамматику, понятную для воспитанников армянского происхождения.

На протяжении всего своего существования детище Лазаревых не раз наталкивалось на противоборство со стороны Министерства народного просвещения, не заинтересованного в развитии сначала училища, а затем - института. С целью обезопасить учебное заведение от нападок министерства Лазаревы, при поддержке Армянской Апостольской церкви, старались находить влиятельных покровителей. Так, в 1824 г. в адрес императора Александра I поступило письмо, подготовленное И.Л. Лазаревым и Католикосом всех армян Ефремом. В нем адресаты обращались к главе государства с просьбой о присвоении Армянскому московскому училищу определенных прав и назначении покровителем учебного заведения графа А.А. Аракчеева (Католикос хорошо понимал значимость фигуры графа в российском государстве). В письме отмечалось: «Армянская нация пылает духом верности к благословенной державе Bсероссийской... я приемлю дерзновение с благоговением всеподданнейше просить Ваше Императорское величество... даровать оной Президента Его Святительство генерала от Артиллерии графа Алексея Андреевича Аракчеева» $[10$, л. 2]. Немногим позже Католикос всех армян Ефрем повторно обратился с подобной просьбой. В письме от 12 мая 1824 года он писал: «...я соединяю мольбу мою со всеми верными церкви нашей Армянами, дабы Высочайшим Вашего Императорского Величества соизволением... звание президента возложено было на Графа Алексея Андреевича Аракчеева» [11, с. 129]. Данное стремление принесло свои плоды, и 30 июня 1825 г. граф А.А. Аракчеев был назначен на должность покровителя училища. Однако через два года он сложил с себя полномочия.

В 1827 г. Армянскому московскому училищу были дарованы новые права и статус, а само училище преобразовано в институт с официальным наименованием - «Армянский Лазаревых институт восточных языков». Новшества требовали особого покровителя, которым, по мнению Лазаревых, мог стать шеф жандармов генерал-адъютант граф Александр Христофорович Бенкендорф (1782-1844) [12, л. 440].
Как и ранее, союзником Лазаревых в решении данного вопроса выступила Армянская Апостольская церковь. 13 января 1828 г. в адрес императора Николая I поступило прошение армянского епархиального архиепископа Иоанесса с просьбой о назначении на вакантную в Лазаревском институте восточных языков должность главного начальника графа А.Х. Бенкендорфа. Архиепископ Иоанесс писал: «Я соединяю мольбу со всеми верными церкви нашей Армянами, дабы Высочайшим соизволением Главного Начальника над восточным сим институтом возложено было ныне на Генерал-Адъютанта Вашего Императорского Величества Александра Христофоровича Бенкендорфа» [11, с. 134]. Выбор Бенкендорфа на данную должность окажется одним из самых удачных. За 16 лет пребывания на своем посту он будет не только содействовать развитию института, но и сможет сохранить статус крупнейшего армянского образовательного учреждения.

Осознавая значимость Армянской Апостольской церкви в деятельности учебного заведения, члены семьи Лазаревых стремились расширить права церкви в стенах института, которые официально были закреплены в новом уставе, принятом 10 мая 1848 г. Согласно тексту документа особое внимание теперь уделялось подготовке юношей для армянского духовенства, а патриарх и католикос всех армян объявлялся почетным членом института и входил в его правление [13, л. 6-6 об.]. В дополнение к прочему за церковью закреплялось право назначения попечителя института в случае пресечения рода Лазаревых.

Параллельно представители армянского духовенства занимались поиском новых кадров для института. В личном фонде Лазаревых сохранилось письмо архиепископа Нерсеса в адрес руководства института, в котором священнослужитель просит принять на должность инспектора преподавателя из Тифлиса С. Тер-Аветисяна. Отмечая качества кандидата, он подчеркивал его «религиозное нравственное влияние на учеников...» [14, л. 9 об.].

\section{Духовное отделение}

В 1841 г. при содействии Армянской Апостольской церкви в Лазаревском институте восточных языков состоялось открытие духовного отделения как «особого отделения для образования юношества духовного звания...» [15, л. 54]. Это позволяло детям из несостоятельных семей армянских священнослужителей получать не только светское, но и теологическое образование.

Текст проекта будущего духовного отделения был разработан к 1840 г. и направлен на рассмотрение святейшему Эчмиадзинскому Верховному патриарху Нерсесу, который вскоре подписал его. Получив одобрение патриарха, главный начальник Лазаревского института А.Х. Бенкендорф направил министру внутренних дел А.Г. Строганову прошение об открытии нового отделения. В ответе на обращение главного начальника института, полученном 14 марта 1841 г., отмечалось, что с целью «улучшения состояния Армянской церкви и образования его духовенства» [11, с. 151] Указом Правительствующего Сената от 4 марта 1841 г. принято решение учредить в Лазаревском институте особое отделение по подготовке юношей для вступления в духовное звание [16, л. 189-191].

В стенах самого института новые положения были закреплены в своде правил, утвержденных 31 ян- 
варя 1841 г. [16]. Согласно новым поправкам Лазаревский институт восточных языков обязывался готовить «юношей из духовного сословия АрмяноГригорианского исповедания для службы по духовному ведомству» [17, с. 87$]$.

Уникальность Лазаревского института заключалась в его многопрофильности, которая сочетала в себе как светское, так и теологическое образование. В Уставе специально для воспитанников, обучающихся с целью дальнейшего посвящения себя духовному званию в рамках Армянской Апостольской церкви, в дополнение к основным предметам (русскому и армянскому языкам, математике, истории, Закону Божьему по армянскому образцу и др.) [13, л. 8], было прописано преподавание истории церкви, Священного Писания и догматического богословия.

Указывая на особенности приема воспитанников в духовное отделение института, отметим, что одним из обязательных требований являлось закрепленное в Уставе хорошее владение русским языком, поэтому при поступлении необходимо было «представлять свидетельство о достаточном знании ими русского языка» $[17$, с. 87]. Это свидетельствует о заинтересованности Лазаревых в скорейшей адаптации, в том числе и представителей армянского духовенства.

Специальные классьл

Говоря о специфике образовательного процесса в Лазаревском институте, следует остановиться также на специальных классах, организованных в 1871 г. Согласно тексту Устава они относились к высшим учебным заведениям, изучающим восточные языки. Примечателен тот факт, что при специальных класcax значился Совет, состоящий из директора и инспектора. В качестве почетного члена в Совет избирался и «Верховный Патриарх - Католикос армянского народа» [18, с. 1145].

\section{Стипендии}

для воспитанников духовного отделения

Воспитанниками Лазаревского института восточных языков в основном становились дети из несостоятельных армянских семей, а это, в свою очередь, требовало серьезного финансирования со стороны благотворителей. К середине XIX в. в учебном заведении уже существовал ряд стипендий, учрежденных частными лицами, в том числе и самими Лазаревыми. С открытием духовного отделения возникла потребность в дополнительных стипендиях, распространявшихся только на воспитанников данного направления. В документах Центрального государственного архива Москвы сохранилось обращение в Совет Лазаревского института некоего П.В. Сариева с прошением о приеме на бесплатное обучение его сына. Однако, в связи с отсутствием свободных стипендий светским воспитанникам, в просьбе ему было отказано. Совет института сообщил о продолжении приема на бесплатное обучение только детей армянских священнослужителей, которые по завершении обучения должны будут «посвятить себя в духовное звание» [19, л. 40].

С целью увеличения приема новых воспитанников в духовное отделение и их материального обеспечения, Совет Лазаревского института при участии Армянской Апостольской церкви обратился к армянским церковнослужителям с предложением их сыновьям поступить на обучение в институт, если они «согласные посвятить себя церковному служению» $[19$, л. 39]. Среди основных требований, предъявляе- мых к кандидатам, значились «умение читать и писать на армянском и русском языках», а также знание первых четырех действий арифметики [19, л. 39]. Для них также устанавливались и возрастные ограничения от 10 до 13 лет. Из этого следует, что члены правления Лазаревского института были не только заинтересованы в увеличении количества воспитанников, но и стремились критически подходить к отбору кандидатов.

\section{Распространение религиозной литературы}

29 июня 1829 г. при Лазаревском институте восточных языков начала действовать типография [20, c. 222]. Для образовательного процесса ее открытие имело важнейшее значение, т.к. литературу на армянском языке институт теперь во многом печатал сам, а не привозил из Закавказья. Вскоре наравне с учебной литературой в типографии начали издавать и религиозную.

В архивном фонде Лазаревского института восточных языков в ЦГАМ сохранилось письмо попечителя института И.И. Лазарева от 27 декабря 1855 г. № 661, информирующего о прибытии из Парижа книг, изданных по заказу института и на его средства. В числе доставленных книг значился труд «История, догматы, предания и литургия Армянской Восточной церкви», подготовленный известным арменистом профессором Дюлерье и армяно-католическим архимандритом Гавриилом Айвазовским, целью которых было «отличить (Армянскую Апостольскую церковь) от Западно-Армянской католической церкви» $[21$, л. 2]. Обращая внимание правления Лазаревского института на значимость труда, И.И. Лазарев указывал, что «перевод догматической книги столь необходим для доказательства православия Апостольской древней армянской церкви» [21, л. 9 об.].

24 июля 1856 г. И.И. Лазаревым в адрес директора Лазаревского института Н.Д. Делянова было подготовлено и направлено письмо с перечнем последних трудов, изданных институтской типографией. Среди наиболее значимых изданий указывалась публикация иллюстрированных книг с биографией представителей семьи Лазаревых в количестве 800 экземпляров. В издание были включены такие иллюстрации, как: «Московская Армяно-григорианская церковь», «Санкт-Петербургская Армяно-григорианская церковь», «Переселение армян в Россию» и портреты представителей семьи Лазаревых [19, л. 40].

\section{Выводы}

Таким образом, на основе проведенного анализа различных направлений деятельности Лазаревского института восточных языков приходим к выводу, что стремление семьи Лазаревых приобщить Армянскую Апостольскую церковь к управлению образовательным учреждением следует считать оправданным. Благодаря участию церкви в жизни института, удалось не только сохранить особенности национальной идентичности у воспитанников армянского происхождения, но и выступить защитником интересов Лазаревского института как одного из центров арменоведения в Российской империи. При их содействии в учебном заведении открывались новые направления, стала публиковаться религиозная литература, учреждались новые стипендии. В истории Лазаревского института восточных языков участие Армянской Апостольской церкви стало одним из элементов уникальности и многопрофильности образовательного учреждения. 
Список литературы:

1. Российский государственный исторический архив. Ф. 880. Оп. 2. Д. 168.

2. Базиянц А.П. Лазаревский институт в истории отечественного востоковедения. М.: Издательство «Наука», 1973. 224 с.

3. Игнатян А.А. История Московского Лазаревского института восточных языков (арм.): дис. ... канд. пед. наук: 13.00.01. Ереван, 1969. 186 с.

4. Ананян Ж.А. Лазаревский институт восточных языков в контексте русского Просвещения // Человек эпохи Просвещения. 1999. № 4. С. 202-218.

5. Саядов С.М. Лазаревы и история армянского народа // Вторые Лазаревские чтения по истории армян России, 25-27 ноября 2003. М., 2006. С. 191-200.

6. Зиновьев А. Исторический очерк Лазаревского института восточных языков с краткой биографией учредителей института. СПб.: Тип. Императорской академии наук, $1855.149 \mathrm{c}$.

7. Братская помощь пострадавшим в Турции армянам. М., 1898.940 с.

8. Российский государственный архив древних актов (РГАДА). Ф. 1252. Оп. 1. Д. 331.

9. Материалы для истории Лазаревского Института восточных языков, издаваемые иждивением г. попечителя князя Семена Семеновича АбамелекЛазарева. М., 1914. Вып. 1. 20 с.

10. РГАДА. Ф. 1252. Оп. 1. Д. 262.

11. Кананов Г.И. Семидесятипятилетие Лазаревского Института восточных языков. 1815-1850 гг. М.: Тип. А.А. Гатцука, 1891. 256 с.

12. Дмитриев А.А. Пермские земледельцы Лазаревы и их преемники князья Абамелеки // Исторический вестник. 1893. Т. 52, № 5. С. 425-447.

13. РГАДА. Ф. 1252. Оп. 1. Д. 263.

14. РГАДА. Ф. 1252. Оп. 1. Д. 300.

15. РГАДА. Ф. 1252. Оп. 1. Д. 17.

16. РГАДА. Ф. 1252. Оп. 1. Д. 390.

17. Полное собрание законов Российской империи. СПб., 1841. Т. 16, № 14235.924 с.

18. Высочайше утвержденный устав Лазаревского института восточных языков // Полное собрание законов Российской империи. СПб., 1875. Собрание 2е. Т. 47. Ч. 2. № 51655.1276 c.

19. Центральный государственный архив Москвы (ЦГАМ). Ф. 213. Оп. 1. Д. 98.

20. Собрание актов, относящихся к обозрению истории армянского народа. М.: Типография Лазаревского института восточных языков, 1838. Ч. ІІІ. 458 с.

21. ЦГАМ. Ф. 213. Оп. 1. Д. 7.

\section{PARTICIPATION OF THE ARMENIAN APOSTOLIC CHURCH IN THE EDUCATIONAL AND ADMINISTRATIVE ACTIVITIES OF LAZAREV INSTITUTE OF ORIENTAL LANGUAGES} (C) 2019

Avetisyan Vladimir Rudolfovich, candidate of historical sciences, head of Publication Department State Archive of the Stavropol Krai (Stavropol, Russian Federation)

Abstract. The Institute of Oriental Languages (Lazarev Institute) throughout its existence (1815-1921) has undergone a number of transformations, namely, having started its activity from a private school, it achieved the status of a state higher educational institution. Understanding a special role of religion in preserving the ethnic characteristics of the Armenian nation in the absence of statehood, prominent Russian public and state figures of Lazarev contributed to strengthening the status of the church within the walls of the institute. Representatives of the Armenian Apostolic Church (AAC) provided all possible assistance to the educational process, first at school, and then at the institute. The apogee in 1841 became the legal consolidation of the rights of the AAC to directly participate in leading the institute and obtaining the status of the honorary member of the institute by the Catholicos. Many Armenian clergies have made a significant contribution to the development of the educational institution, acting as a guarantor of the cultural foundations of the Armenian people. With the assistance of the church, new directions acted at the Lazarev Institute, scholarships were established, and literature was published. The materials obtained during the research can serve as a basis for further studying the role of church organizations in the educational life of secondary and higher educational institutions of the country.

Keywords: Armenian Apostolic Church; Armenian Gregorian Church; Lazarev Institute of Oriental Languages; Armenian Moscow School; Lazarev; education; spiritual department; special classes; church scholarships; Armenian community; Moscow; Catholicos of All Armenians Efrem; patriarch Nerses.

УДК 343.812 (091) (470.56)

DOI $10.24411 / 2309-4370-2019-11206$

Статья поступила в редакцию 12.01.2019

\section{ОБЩЕУГОЛОВНЫЕ ТЮРЬМЫ РОССИЙСКОМ ИМПЕРИИ В ХІХ ВЕКЕ (НА ПРИМЕРЕ ОРЕНБУРГСКОЙ ГУБЕРНИИ)}

(C) 2019

Кузнецова Юлия Владимировна, кандидат исторических наук, доцент кафедры истории и философии Оренбургский государственный аграрный университет (г. Оренбург, Российская Федерачия)

Аннотащия. В статье предпринята попытка на основе архивных и опубликованных материалов дать краткую характеристику состояния общеуголовных тюрем Российской империи в XIX в. на примере Оренбургской губернии. В первой половине XIX веке многие тюремные здания находились в ветхом состоянии, при этом большинство из них были деревянные. Заключённые страдали от перенаселения камер, не разделялись по полу и возрасту, больные содержались вместе со здоровыми, голодали, жили подаянием. Очень часто помещениями для тюрем служили частные наёмные дома. Медицинский персонал в тюрьмах отсутствовал, случались 